HELMINTHOLOGIA, 55, 4: 350 - 362, 2018

\title{
Update on selected topics in acanthocephalan parasites research
}

\author{
Article info \\ Received May 31, 2018 \\ Accepted June 30, 2018
}

\begin{abstract}
Summary
The respectable community of parasitologists aimed at the broad-spectral research of acanthocephalan parasites met at the $9^{\text {th }}$ Acanthocephalan Workshop. The workshop took place in the beautiful surroundings of the High Tatras, Slovakia in the Congress Centre Academia, Stará Lesná near Tatranská Lomnica on September $9-13^{\text {th }}$. This special event was hosted by the Slovak Society for Parasitology, the Institute of Parasitology of the Slovak Academy of Sciences, Košice, Slovakia, and the Czech University of Life Sciences Prague, Czech Republic. It consisted of nearly three dozen lectures presented by distinguished acanthocephalan specialists who came from 13 countries and five continents. Vibrant discussions and creating new plans for future collaborations were accompanied by local mountain touring that offered the venue richly endowed with nature, deep forests and beautiful mountains. The contributions were addressed to resolve current systematic, taxonomic, biological, behavioural, ecological, and related topics. Presented results showed the most recent progressive developments comparable with all the other parasitic worm groups. The $10^{\text {th }}$ Acanthocephalan Workshop will be hosted by Dr. Marie-Jeanne Perrot-Minnot, Université de Bourgogne Franche-Comté, Dijon, Bourgogne, France, in 2022.
\end{abstract}

When citing this Review, please use the following form:

Authors of the cited part (2018): Title of the cited part. In: Update on selected topics in acanthocephalan parasites research. Helminthologia, 55(4): pages. DOI: 10.2478/helm-2018-0023

see the example below:

Amin, O.M. (2018): Variability in the Acanthocephala. In: Update on selected topics in acanthocephalan parasites research. Helminthologia, 55(4): 350 - 361. DOI: 10.2478/helm-2018-0023

\section{SYSTEMATICS AND TAXONOMY}

Variability in the Acanthocephala

\section{OMAR M. AMIN}

Parasitology Center, Inc. (PCI) and Institute of Parasitic Diseases (IPD), Scottsdale, AZ 85259 USA

E-mail: omaramin@aol.com.Web sites: www.parasitetesting.com, www.PClwellness.com.

Unique and unusual features in the many species of acanthocephalans described by Amin from fish, amphibians, reptiles, birds, and mammals, in various parts of the world including South America, Vietnam, Japan, the United States, the Middle East, and North and East Africa, are described. The presentation is in five parts. (1) An introductory section dealing with the classification, general morphology, ecology, and life cycles of the Acanthocephala. (2) Unusual anatomical features of taxonomic or of questionable taxonomic importance addressing variations in the proboscis, proboscis hooks, male and female reproductive organs, and lemnisci. Newly described structures including (a) Para-receptacle structure (PRS) and hoods in certain species as well as a new order of Acanthocephala from Vietnamese birds, are also featured. (3) Structural and functional relationships explaining the relationship between the metamorphosis of the giant nuclei in Eoacanthocephala and worm reproductive cycle. (4) Host-parasite relationships elucidating the relationships between worm anatomy and biology during worm growth. (5) Curiosities in reviews and revisions highlighting taxonomically based zoo-geographical patterns and trends 
in the genera Neoechinorhynchus, Polymorphus, and Pallisentis. A comprehensive treatment of the acanthocephalans of South America and those marine forms off the Eastern United States is also included here. A look at the September, 2013 classification scheme of the Acanthocephala is included covering 4 classes, 26 families, 157 genera, and 1298 species are included

Acanthocephalans in the Helminthological collection of the Institute of Parasitology (IPCAS), České Budějovice, Czech Republic

\section{TOMÁŠ SCHOLZ*, BLANKA ŠKORÍKOVÁ}

Institute of Parasitology, Biology Centre of the Czech Academy of Sciences, Branišovská 31, 37005 České Budějovice, Czech Republic

*Corresponding author: tscholz@paru.cas.cz

The Institute of Parasitology of the Biology Centre of the Czech Academy of Sciences (IPCAS) is a governmental research institution established in Prague in 1962 and relocated to České Budějovice (Budweis) in South Bohemia in 1985. It is the principal institution in the Czech Republic devoted exclusively to basic parasitological research including helminthology. Thanks to the effort of František Moravec, world expert in the systematics of fish nematodes and former curator, the Institute hosts one of the largest helminthological collections in Central Europe. The collection is extraordinarily rich mainly in fish helminths such as nematodes and monogeneans. However, collection of acanthocephalans is also worth mentioning as it includes a total of 107 species (92 identified to the species level) of 7 orders and 18 families; as many as 80 species are from fishes. Type specimens of 16 species (holotypes of 8 taxa) are also deposited in the collection; 14 of them are parasites of teleosts, one of amphibians and one of mammals. In two cases, the new species were type species of newly erected genera, namely Pseudogorgorhynchus Moravec, Wolter et Körting, 2000 and Sharpilosentis Lisitsyna, Scholz et Kuchta, 2015, both from fishes. Specialists in acanthocephalan taxonomy are much welcome to request specimens deposited in the IPCAS. Deposition of type and voucher material of any acanthocephalans in the future would be much appreciated.

An integrated taxonomic approach to understanding species diversity of fish-parasitizing Neoechinorhynchus species

\section{FLORIAN REYDA ${ }^{1 *}$, MARGARET DOOLIN ${ }^{1}$, ANNA PHILLIPS ${ }^{2}$}

${ }^{1}$ Biology Department, State University of New York, College at Oneonta, Oneonta, New York, USA

${ }^{2}$ National Museum of Natural History, Smithsonian Institution, Washington, D.C., USA

${ }^{*}$ Corresponding author: Florian B. Reyda, Ph.D., e-mail: Florian. Reyda@oneonta.edu
Neoechinorhynchus Stiles and Hassall, 1905 is a highly diverse and widespread genus of acanthocephalan that parasitizes fishes and turtles on six continents. The literature base for the genus grew rapidly throughout the $20^{\text {th }}$ century, mostly as a result of original descriptive work recognizing the diversity across the world. There have been, however, relatively few contributions regarding North American species of Neoechinorhynchus since the turn of the $21^{\text {st }}$ century, and a particular lack of use of modern molecular tools. Several recent studies used DNA sequence data to understand species relationships and uncover cryptic species of Neoechinorhynchus in Mexico, but there is still no molecular phylogenetic analysis focused on species of Neoechinorhynchus from the USA or Canada. Here we present the phylogenetic results of the first such study, based on nuclear DNA from the internal transcribed spacer (ITS) and large ribosomal unit (LSU) regions, including molecular data from multiple specimens of each of 17 total species (two from turtles and 15 from fishes) from the United States and Canada. We also present morphological evidence supporting the boundaries of several of these species. In addition to giving the first look at relationships between these species, this work has uncovered three previously uncharacterized species from white suckers of Central New York State. Plus, we have found that a species of another neoechinorhynchid genus, Octospinifer van Cleave, 1919 nests among species of Neoechinorhynchus, lending further support to the recently recognized paraphyly of this large and somewhat enigmatic genus.

Pomphorhynchus spp. in the Rhine system - recent situation and future perspectives

\section{SEBASTIAN VOGEL}

Institute of Zoology, Department of Ecology and Parasitology, Karlsruhe Institute of Technology (KIT), Kornblumenstraße 13, 76131 Karlsruhe, Germany. e-mail: Sebastian.vogel9@kit.edu

Over the last few years contrasting results regarding the distribution of two previously synonymised acanthocephalan species, Pomphorhynchus laevis and Pomphorhynchus tereticollis, have been published for the Rhine river system. Shortly after its redescription, Emde et al. (2012) stated a high invasive potential for $P$. tereticollis, due to its occurrence in the invasive round goby. Recently, a contradictory study by Hohenadler et al. (2018) showed a gradual replacement of $P$. tereticollis by $P$. laevis in eel. However, a distinction between the two congeners remains difficult, since both studies used either a morphological or molecular approach for the differentiation and furthermore, they only took account of unsuitable hosts. Hence, fish of different taxa from the Upper Rhine near Karlsruhe were examined for acanthocephalan infestation to clarify the recent distribution of the congeners.

To facilitate distinguishing between the two species, randomly selected Pomphorhynchus worms were verified molecularly by 
sequencing the COI-locus. Proboscis hooks of the same specimens were counted and measured, allowing the analysis of hook patterns with the Proboscis Profiler (Wayland, 2010). Significant differences between the proboscis armature of $P$. laevis and $P$. tereticollis allowed a sufficient species separation. Principal Component Analysis of the hook profiles revealed a correlation between molecular and morphometric traits, thus yielding a potential new option for morphological determination.

Examination showed high infection rates with mature $P$. laevis in common barbel and chub, while $P$. tereticollis was only found at low abundance in chub and brown trout. For the first time co-infections of both species are recorded in an individual host. Unsuitable hosts, such as catfish, eel and round goby, were exclusively infected with immature $P$. laevis. In light of the recent findings the distribution of Pomphorhynchus spp. in the Rhine River and tributaries is discussed, as well as the influence of invasive Ponto-Caspian fish and amphipod species as acanthocephalan hosts have been re-evaluated.

References:

Emde, S., Rueckert, S., Palm, H.W., Klimpel S. (2012): Invasive Ponto-Caspian amphipods and fish increase the distribution range of the acanthocephalan Pomphorhynchus tereticollis in the River Rhine. PLOS ONE 7(12): e53218. https://doi.org/10.1371/journal. pone.0053218

Hohenadler, M.A.A., Nachev, M., Thielen, F., Taraschewski, H., Grabner, D., Sures, B. (2018): Pomphorhynchus laevis: An invasive species in the river Rhine? Biol. Invasions, 20(1): 207 - 217. DOI: 10.1007/s10530-017-1527-9

WaYLAND, M.T. (2010): Proboscis profiler: a tool for detecting acanthocephalan morphotypes. Syst. Parasitol., 76(3): 159 - 167. DOI: 10.1007/s11230-010-9245-z

\section{Never-ending story of Pomphorhynchus spp. - back to the type material?}

\section{MARTA ŠPAKULOVÁ ${ }^{1,2}$, MARTINAOROSOVÁ1, MARIE-JEANNE PERROT-MINNOT ${ }^{3}$}

${ }^{1}$ Institute of Parasitology, Slovak Academy of Sciences, Hlinkova 3, 04001 Košice, Slovakia

${ }^{2}$ Czech University of Life Sciences Prague, FAFNR, Kamýcká 129, Praha 6 - Suchdol, Czech Republic

3 Biogéosciences, UMR 6282 CNRS, Université Bourgogne Franche-Comté, 6 Boulevard Gabriel, 21000 Dijon, France

Pomphorhynchus laevis (Zoega in Müller, 1779) was considered to be the predominant species in European fishes for a long time, characterized by high morphological and physiological intraspecific variability (e.g. Kennedy,1984). During the first decade of the 21st century, previously synonymised Pomphorhynchus tereticollis (Rudolphi, 1809) was ressurrected (Bombarová et al., 2007; Špakulová et al., 2011): taking into account the ICZN rules, the Ru- dolphi's type material was compared with newly collected worms from the type locality (Baltic coast) and the type fish host (Platichthys flessus), and the worm morphology was combined with new comparative genetic characteristics (gene sequencing, karyotype). The existence of these species is apparent but their distinction is difficult. The same applies to other congeners described so far in Europe using only morphological tools. The latest extensive study of $P$. laevis and $P$. tereticollis phylogeography throughout Western Palaearctic (Perrot-Minnot et al., 2018) showed that $P$. tereticollis occurs within Western and Central parts of Europe showing weak geographical and genetic structuring, while $P$. laevis sensu lato is representing by five lineages partially matching several major biogeographical regions. That means we have a big task ahead of us - i.e. to harmonize so far existing European Pomphorhynchus species with the recently described lineages, re-describe their morphology, and to re-establish species spectrum within the whole Europe including its Peri-Mediterranean and Ponto-Caspian parts. The best way may probably be to use newly acquired acanthocephalans from type localities and type fish hosts (in the absence of ethanol-fixed material in museum collections). Further, re-descriptions on basis of integrative approaches should include morphology, gene sequencing and maybe also chromosome analysis. A promising beginning may be Pomphorhynchus spp. from Sava River, the Işıklı Lake, the Volga River etc.

References:

Bombarová, M., Marec, F., Nguyen, P., Špakulová, M. (2007): Divergent location of ribosomal genes in chromosomes of fish thorny-headed worms, Pomphorhynchus laevis and Pomphorhynchus tereticollis (Acanthocephala). Genetica, 131(2): 141 - 149. DOI: 10.1007/s10709-006-9124-3

Kennedy, C.R. (1984): The status of flounders, Platychthys flessus (L.) as hosts of the acanthocephalan Pomphorhynchus laevis (Müller) and its survival in marine conditions. J. Fish Biol. L'č: 135 - 149. https://doi.org/10.1111/j.1095-8649.1984.tb04785.x Perrot-Minnot, M.-J., Špakulová, M., Wattier, R., Kotlík, P., Düsen, S., Aydogdu, A., Tougard, CH. (2018): Contrasting phylogeography of two Western Palaearctic fish parasites despite similar life cycles. J. Biogeogr., 45(1): 101 - 115. DOI: ttps://doi.org/10.1111/ jbi.13118.

Š́akulová, M., Perrot-Minnot, M.-J., Neuhaus, B. (2011): Resurrection of Pomphorhynchus tereticollis (Rudolphi, 1809) (Acanthocephala: Pomphorhynchidae) based on new morphological and molecular data. Helminthologia, 48(4): 268 - 277. DOI: https:// doi.org/10.2478/s11687-011-0038-y

This work was supported by VEGA 2/0159/16. 
Integrative taxonomy of acanthocephalans from Brazilian mammals

\section{ANA PAULA NASCIMENTO GOMES ${ }^{1,2 *}$, NATALIE OLIFIERS ${ }^{3}$, ROBERTO DO VAL VILELA ${ }^{1}$, CLARICE SILVA CESÁRIO ${ }^{4}$, RITA DE CASSIA BIANCHI ${ }^{4}$, ARNALDO MALDONADO JR. ${ }^{1}$}

\author{
${ }^{1}$ Laboratório de Biologia e Parasitologia de Mamíferos Silvestre \\ Reservatório, Instituto Oswaldo Cruz, Fundação Oswaldo Cruz. \\ Avenida Brasil, 4365 Manguinhos, Rio de Janeiro, Rio de Janeiro, \\ Brazil \\ 2 Pós Graduação em Biologia Parasitária, Instituto Oswaldo Cruz, \\ Fundação Oswaldo Cruz, Rio de Janeiro, Rio de Janeiro, Brazil. \\ ${ }^{3}$ Universidade Veiga de Almeida, Rua Ibituruna, 108, Maracanã, \\ Rio de Janeiro, Rio de Janeiro, Brazil \\ 4 Departamento de Biologia Aplicada à Agropecuária, Universi- \\ dade Estadual Paulista "Júlio de Mesquita Filho", Jaboticabal, São \\ Paulo, Brazil \\ ${ }^{*}$ Corresponding author
}

Since the early twentieth century, species of acanthocephalans have been reported in mammals from different geographic regions in Brazil (Vieira et al. 2008). However, there is still a lack of adequate, complete taxonomic, phylogenetic and ecological information regarding these species. As part of a $\mathrm{PhD}$ project carried out with the support of the Oswaldo Cruz Foundation (FIOCRUZ), Rio de Janeiro, Brazil, we aimed to identify acanthocephalan species collected from wild mammals in Brazil and investigate their phylogenetic relationships. Specimens of acanthocephalans were identified based on morphological and morphometric features using light and scanning electron microscopy and DNA analyses. We identified Gigantorhynchus echinodiscus (Gigantorhynchidae) in a giant anteater, Myrmecophaga tridactyla, from the Cerrado in the state of São Paulo. Although the species has been previously reported in this host, genetic data were absent. Our study provides details on the structures as a bipartite cylindrical proboscis with a crown of 18 hooks and numerous small hooks, pseudo-segmented body, long leminisci, large testes and ovoid eggs. Such features agree with the genus Gigantorhynchus characteristics (Yamaguti, 1963). Our genetic study included new sequences of partial $28 \mathrm{~S}$ rRNA gene. Phylogenetic analyses were inferred using maximum-likelihood in PhyML 3.0 and Bayesian analysis in MrBayes version 3.2.6, this last using the CIPRES platform. Results showed that $\mathrm{G}$. echinodiscus is closely related to Mediorhynchus sp., both forming a well-supported monophyletic group (scores $=0.92 / 0.95$ ). The family Gigantorhynchidae includes two genera, Gigantorhynchus and Mediorhynchus, both possessing bipartite proboscis with large hooks and small hooks, pseudo-segmented body, long or short and slender leminisci, large testes, eight compact cement glands and ovoid eggs. Genetic data were congruent with morphological studies, classifying both species within the family Gigantorhynchidae (Amin, 2013). This study extends our knowledge about acanthocephalans from Brazilian mammals, emphasizes the importance of integrative taxonomic studies to better understand their taxonomy and evolution.

References:

Amin, O.M. (2013): Classification of the Acanthocephala. Folia Parasitol., 60(4): 273 - 305. DOI: 10.14411/fp.2013.031.

Vieira, F.M., Luque, J.L., Muniz-PereiRA, L.C. (2008): Checklist of helminth parasites in wild carnivore mammals from Brazil. Zootaxa, 1721: 1 - 23. DOI: 10.5281/zenodo. 181136

Yamaguti, S. (1963): Acanthocephala. Systema Helminthum, Vol. 5. John Wiley and Sons Interscience, New York, London, 5: 1 - 423.

Redescription of Acanthogyrus (Acanthosentis) maroccanus (Dollfus, 1951) (Acanthocephala: Quadrigyridae) from the Algerian barb Luciobarbus callensis (Cypriniformes: Cyprinidae) from Algeria

\section{AMEL MENASRIA ${ }^{1 *}$, NOUHA KAOUACHI', DANIEL BARČÁK², MOURAD BENSOUILAH ${ }^{3}$, JESÚS S. HERNÁNDEZ-ORTS ${ }^{4}$}

${ }^{1}$ Laboratory of Aquatic and Terrestrial Ecosystems, Faculty of Science, Mohamed Cherif Messadia University, Souk Ahras, Algeria

${ }^{2}$ Institute of Parasitology, Slovak Academy of Sciences, Hlinkova 3, 04001 Košice, Slovakia

${ }^{3}$ Laboratory of Ecobiology for Marine Environments and Coastlines, Faculty of Science, Badji Mokhtar University-Annaba, Annaba, Algeria

${ }^{4}$ Centro de Investigación Aplicada y Transferencia Tecnológica en Recursos Marinos Almirante Storni (CIMAS - CCT CONICET CENPAT), San Antonio Oeste, Río Negro, Argentina

${ }^{*}$ Corresponding author

The fresh water acanthocephalan Acanthogyrus (Acanthosentis) maroccanus Dollfus, 1951 was insufficiently described in Luciobarbus setivimensis (Cypriniformes: Cyprinidae) in Morocco. Although this acanthocephalan has been reported from cyprinid fishes in northern Africa, its detailed morphological description has never been provided. In this study, we present novel morphological data including scanning electron microscopy micrographs (SEM), based on specimens found in the Algerian barb Luciobarbus callensis from the Oued Charef Dam Lake, Algeria. The most typical characteristics of $A$. maroccanus are: (i) short proboscis armed with 3 incomplete circles of 6 rooted hooks each; (ii) proboscis hooks of different lengths; (iii) trunk shorter than $8.5 \mathrm{~mm}$; (iv) trunk with 17-19 circles of spines, covering almost completely the anterior part of the trunk; (v) 3-4 ventral and 6-8 dorsal giant hypodermal nuclei; and (vi) male reproductive structures (sperm duct and Saefftigen's pouch) extending into bursa. Our observation also revealed the presence of the parareceptacle structure and vaginal sleeve in females of $A$. maroccanus from Algeria. Additionally, we obtained partial sequences of the large ribosomal subunit (28S) and mitochondrial cytochrome c oxidase 1 (cox1) 
genes for this species; representing the first molecular data for the species-rich genus Acanthogyrus Thapar, 1927.

References:

Dollfus, R. (1951): Miscellanea helmintologica Maroccana. I. Quelques trematodes, cestodes et acanthocephales. Arch. Inst. Pasteur Maroc., 4: 104 - 229.

\section{Acanthocephalans from California sea lions (Zalophus cali- fornianus): New records and evidence for synonymy of Corynosoma obtuscens with Corynosoma australe}

OLGAI. LISITSYNA ${ }^{1 *}$, OLENA KUDLAI ${ }^{2,3}$, TERRY R. SPRAKER ${ }^{4}$, VASYL TKACH ${ }^{5}$, LESLEY R. SMALES ${ }^{6}$, TETIANA KUZMINA ${ }^{1}$

1I. I. Schmalhausen Institute of Zoology NAS of Ukraine, Bogdan Khmelnytsky street, 15, Kyiv 01030, Ukraine; olisitsyna@izan. kiev.ua; taniak@izan.kiev.ua

${ }^{2}$ Institute of Ecology, Nature Research Centre, Akademijos, 2, 08412, Vilnius, Lithuania

${ }^{3}$ Water Research Group, Unit for Environmental Sciences and Management, Potchefstroom Campus, North-West University, Potchefstroom 2520, South Africa

${ }^{4}$ Department of Microbiology, Immunology and Pathology, College of Veterinary Medicine and Biomedical Sciences, Colorado State University, Fort Collins, CO, 80526, USA

${ }^{5}$ Department of Biology, University of North Dakota, 10 Cornell Street, Grand Forks, North Dakota 58202-9019, USA

${ }^{6}$ Parsitology Section, South Australian Museum, North Terrace, Adelaide 5000, Australia

*Corresponding author

California sea lions (CSLs) (Zalophus californianus) are one of the most abundant and recognized pinniped species in the North Pacific. To increase the limited knowledge addressing acanthocephalans parasitizing CSLs, 33 animals including pups, juvenile and adult sea lions were examined at The Marine Mammal Center (TMMC), California, USA, in 2012, 2015 and 2016. Totally, 2,268 specimens of acanthocephalans representing 5 species from three genera Andracantha (A. phalacrocoracis and Andracantha sp.), Corynosoma (C. strumosum, C. obtuscens) and Profilicollis ( $P$. altmani) were found. The total prevalence was $73 \%$ and intensity of infection varied from 1 to 1,225 (average $=94.5$; median = 19). $P$. altmani and $A$. phalacrocoracis, predominantly parasites of fish-eating birds, were registered in CSLs for the first time and only in juvenile CSLs. Significant differences were observed in the species diversity in different age groups of CLSs. Detailed morphological and molecular examinations of $C$. obtuscens collected from CSLs gave us solid evidences for a synonymy of this species with Corynosoma australe. Comparison of the metrical and quantitative characters of 51 specimens of $C$. obtuscens ( 24 males, 27 females) from CSLs from California, USA and published data on $C$. australe from different hosts and regions, including type material of the both species (Johnston, 1937; Smales, 1986; Hernández-Orts et al., 2017) did not reveal any significant differences between these species. The level of the genetic divergence in the cox 1 sequences from $C$. obtuscens from CSLs and $C$. australe from others marine mammals and penguins reaching $1.4-1.6 \%$ can be considered as an intraspecific variability. Thus, according to the rule of priority the name $C$. obtuscens should be recognized as the junior synonym of $C$. australe.

References:

Hernández-Orts, J. S., Brandao, M., Georgieva, S., Raga, J. A., Crespo, E. A., Luque, J. L. \& Javier, F. (2017): From mammals back to birds: Host-switch of the acanthocephalan Corynosoma australe from pinnipeds to the Magellanic penguin Spheniscus magellanicus. PLOS ONE, 12(10): e0183809. DOI: 10.1371/journal.pone.0183809

Johnston, T. H. (1937): Entozoa from the Australian hair seal. Proc. Linn. Soc. N. S. W., 62: $9-16$.

SMALES, L.R. (1986): Polymorphidae (Acanthocephala) from Australian mammals with description of two new species. Syst. Parasitol., 8(2): 91 - 100. DOI: 10.1007/BF00009865

\section{Acanthocephalans from common carp (Cyprinus carpio L.) from the Yangtze River basin, China}

\section{OLGA LISITSYNA ${ }^{1}$, BING-WEN XI², MIKULÁŠ OROS ${ }^{3 *}$}

1. I. Schmalhausen Institute of Zoology, National Academy of Sciences of Ukraine, Bogdan Khmelnytsky street 15, Kyiv 01030 , Ukraine

${ }^{2}$ Key Laboratory of Freshwater Fisheries and Germplasm Resources Utilization, Ministry of Agriculture, Freshwater Fisheries Research Center, Chinese Academy of Fishery Sciences, Wuxi, China

${ }^{3}$ Institute of Parasitology, Slovak Academy of Sciences, Hlinkova 3, 04001 Košice, Slovak Republic

* Corresponding author

Within the years 2009-2018, a total of 1,687 fish specimens belonging to 36 species of 11 families were collected and examined for intestinal parasites throughout the Yangtze River basin. The present work resumes acanthocephalan parasites from the family Illiosentidae Golvan, 1960 collected from the intestine of common carp (Cyprinus carpio L.) from the Tai Hu Lake in Wuxi, Jiangsu Province, China. A total of 17 market-size common carps (total length of $30-50 \mathrm{~cm}$ ) were purchased at the fish market or from local fishermen and examined. In total, 21 specimens of acanthocephalans were found in 6 carps (prevalence of $35 \%$ ). Worms were washed in tap water, relaxed in refrigerator and then fixed in $4 \%$ formalin solution under slight pressure. Several specimens were fixed in $96 \%$ molecular-grade ethanol for molecular analyses. For final morphological examination, temporary microscopic preparations in Berlese's medium were made; line drawings were made using a drawing attachment on a Zeiss Axio Imager M1 compound 
microscope equipped with DIC optics and a digital imaging system. All the studied specimens were assigned to the Illiosentidae based on the family-specific morphology of the worms and the presence of 8 cement glands in males. However, specimens recently found in the common carp differed from all the existing genera of the family Illiosentidae by the i) structure of the reproductive system of females, i.e. vagina lacking a muscular sphincter; ii) presence of the terminally pointed protruding tail end in the form of a dome with a muscular base; iii) proboscis receptacle having a goblet-shaped widening in the anterior part of worms of both sexes, absent in representatives of other genera. In addition, recently found specimens are the only representatives of the family Illiosentidae hitherto found in freshwater ecosystems; all other species of the family were referred to parasitize marine fish. Therefore, a new acanthocephalan genus and species are to be proposed from the carp C. carpio from the Yangtze River basin, China.

This work was supported by the Slovak Research and Development Agency under the contract No. SK-CN-2017-0007

\section{DIVERSITY AND GEOGRAPHICAL DISTRIBUTION}

\section{Acanthocephala from sharks and rays (Elasmobranchii)}

\section{LESLEY SMALES*, DIANE BARTON, LESLIE CHISHOLM}

South Australian Museum, North Terrace, Adelaide, SA 5000, Australia

${ }^{*}$ Corresponding author

Acanthocephalan parasites, although relatively common in bony fish, are not usually found in cartilaginous fish (sharks and rays) and parasite-host switching between bony and cartilaginous fishes has not been reported. On occasion infections of elasmobranchs have been recorded, but usually the infection has been light, the worms not mature, or a single worm only recovered. In such instances the infections have either been considered accidental, or, in some circumstances, the result of an infected definitive host being consumed by the shark or ray. At least 14 species of acanthocephalan have been so recorded. A further 4 species have been described only from elasmobranchs (Weaver \& Smales, 2014). Dissection of elasmobranchs from Australian waters is continuing and here we present preliminary results. Firstly, the probable accidental infection of Sphyrna mokarran, the great hammerhead, with Corynosoma cetaceum whose usual hosts are dolphins. Secondly, an as yet undescribed species from the wobbegong, Sutorectus tentaculatus. In this case the worms, males and females up to 50 $\mathrm{mm}$ long, were mature and the females were gravid. The species cannot be easily placed in any family and the morphologically similar species have not been recorded from any other fish found in Australian waters. This represents the fifth example of a species known only from elasmobranchs and indicates that in some cir- cumstances elasmobranchs may act as suitable definitive hosts for acanthocephalan parasites.

References:

Weaver, H.J., Smales, L.R. (2014): Two species of Acanthocephala (Rhadinorhynchidae and Transvenidae) from elasmobranchs from Australia. Comp. Parasitol., 81(1): 110 - 113. DOI: 10.1654/4654.1

Acanthocephalans in northern fur seals (Callorhinus ursinus) from St. Paul Island, Alaska: results of four-year observations

\section{TETIANA KUZMINA ${ }^{1 *}$, OLGA I. LISITSYNA ${ }^{1}$, TERRY R. SPRAKER ${ }^{2}$}

${ }^{1}$ I. I. Schmalhausen Institute of Zoology NAS of Ukraine, Bogdan Khmelnytsky street, 15, Kyiv 01030, Ukraine;

2Department of Microbiology, Immunology and Pathology, College of Veterinary Medicine and Biomedical Sciences, Colorado State University, Fort Collins, CO 80526, USA

*Corresponding author: taniak@izan.kiev.ua

Several species of acanthocephalans (Acanthocephala: Polymorphidae) are known to parasitize in northern fur seals (NFSs) (Callorhinus ursinus). Acanthocephalans from the genera Corynosoma and Bolbosoma were found in NFSs in different parts of their range, including the NFSs from the Pribilov Islands (St. Paul and St. George Islands), where about $50 \%$ of the NFS world population have breeding rookeries. The aim of the present study was to examine a species diversity of acanthocephalans parasitizing the NFSs at different rookeries of St. Paul Island, Alaska. During 2011-2014, gastrointestinal tracts of 756 humanely harvested NFS subadult males were examined during the annual Aleut subsistence harvest at five rookeries: Lukanin (165), Polovina (164), Gorbatch (125), Zapadnyj (182) and Morzhovyi (120). All acanthocephalans (1,170 specimens) were collected manually, fixed in $70 \%$ ethanol and identified by the morphology after their clarification in the Berlese medium. Totally, 8 species of acanthocephalans from two genera Corynosoma and Bolbosoma were found in NFSs with a total prevalence of $43.4 \%$. Corynosoma strumosum was the most prevalent species $(20.9 \%)$; the prevalence of the other species was lower: C. similis - $13.5 \%$, C. semerme - $14.6 \%$, C. villosum $-12.8 \%$, C. validum $-1.9 \%$, C. alaskensis $-0.1 \%$, C. cameroni $-0.7 \%$, B. nipponicum $-1.6 \%$. The intensity of infection of acanthocephalans in NFSs was low - from 1 to 31 (average $=3.6 \pm 4.3$; median $=2$ ) parasites per seal. Differences in the species composition and prevalence were observed in NFS subpopulations from the five rookeries. The highest biodiversity of acanthocephalans was observed in subpopulations from Morzhovyj rookery (8 species); the lowest - in Lukanin (6 species). Comparison of our results with data previously collected in Alaska and other parts of the North Pacific revealed a decrease of the NFS infection with acanthocephalans during last four decades. 
Diversity of Acanthocephala in some teleost fishes from Kalaat El Andalous, Tunisia

\section{CHIRAZ BEN SAAD*, HALIMA JMII CHINE, LAMIA GARGOURI}

University of Tunis El Manar, Faculty of Sciences of Tunis, Research Unit Bio-Ecology and Systematic Evolutionary, 2092, Tunis, Tunisia

${ }^{*}$ Corresponding author

In Tunisia, the first record of Acanthocephala was reported in 2015 from the Bizerte lagoon. In order to improve knowledge about this group, we extended our investigations to other localities such as lagoon and sea of Kalaat El Andalous (NorthernTunisia). During two years (April 2015 to May 2017), a total of 671 fishes belonging to four families, Gobiidae (Gobius niger, G. paganellus and G. geniporus), Scorpaenidae (Scorpaena porcus), Sparidae (Lithognathus mormyrus) and Belonidae (Belone belone and $B$. gracilis) were examined. Acanthocephalans were collected from the digestive tract of the fish and identified on the basis of the morphological features. The present study allowed us to identify three families of Acanthocephala including Illiosentidae Golvan, 1960: Telosentis exiguus von Linstow, 1901, Arhythmacanthidae Yamaguti, 1935: Acanthocephaloides propinquus Dujardin, 1845 and $A$. irregularis Amin, Oğuz, Heckmann, Tepe \& Kvach, 2011, and Echinorhynchidae Cobbold, 1879: Acanthocephalus lucii Müller, 1776. The solution of parasitic infra-communities showed that they are species-poor; $75.90 \%$ of fishes harboured only a single parasite species, whilst $23.09 \%$ of them were infected with two species of Acanthocephala. Telosentis exiguus and A. propinquus were found along the entire digestive tract, whereas $A$. irregularis and A. lucii were restricted to its posterior part. The overall dynamics of the parasitism showed that $T$. exiguus is the most frequent species with the highest percentage of the prevalence $(23.58 \%)$ in $G$. niger. Acanthocephaloides irregularis and $A$. lucii were reported only in S. porcus and L. mormyrus, respectively. Acanthocephalus lucii was recorded in L. mormyrus from the Mediterranean Sea for the first time. The data of the present study were compared with results available from other localities and countries.

References:

Amin, O. R., Oguz, M. C., Heckmann, R. A., Tepe, Y., Kvach, Y. (2011): Acanthocephaloides irregularis n. sp. (Acanthocephala: Arhythmacanthidae) from marine fishes off the Ukrainian Black Sea coast. Syst. Parasitol., 80: 125 -135. DOI: 10.1007/s11230011-9312-0

Gargouri, L., Antar, R., Zarrouk, F., MaAmouri, F. (2015): The occurrence of acanthocephalans in teleost fish from the Bizerte lagoon, Tunisia. J. Helminthol., 90(1): 96 - 101. DOI: 10.1017/ S0022149X15000048

NEAR T. J. (2002): Acanthocephalan phylogeny and the evolution of parasitism. Integr. Comp. Biol., 42(3): 668 - 677. DOI: https://doi. org/10.1093/icb/42.3.668

\section{Acanthocephalans of Carangidae and Mullidae from Northern} Tunisia: Ecology and morphology.

\section{HALIMA JMII CHINE*, CHIRAZ BEN SAAD, LAMIA GARGOURI}

University of Tunis El Manar, Faculty of Sciences of Tunis, Research Unit Bio-Ecology and Systematic Evolutionary, 2092, Tunis, Tunisia

${ }^{*}$ Corresponding author

The acanthocephalan fauna of fish is poorly known in Tunisian waters and published data are restricted to those of Gargouri et al. (2015). In order to fill this gap, our survey is focused on acanthocephalans of commercially important fish in Bizerte Lagoon (Northern Tunisia). A total of 470 fish specimens belonging to Carangidae (Trachurus trachurus, Caranx rhonchus, Trachinotus ovatus) and Mullidae (Mullus surmuletus) were collected and examined for thorny headed worms. Five acanthocephalan species belonging to four different families were recovered, namely two species of Arhythmacanthidae Yamaguti, 1935: Acanthocephaloides sp. Meyer, 1932 and Breizacanthus irenae Golvan, 1969, and one of Illiosentidae Golvan, 1960: Telosentis exiguus (von Linstow, 1901), Polymorphidae Meyer, 1931: Southwellina hispida Van Cleave, 1925 and Pomphorhynchidae Yamaguti, 1939: Longicollum pagrosomi Yamaguti, 1935, respectively. The species showed flexibility in the spatial distribution within the host intestine being present in different parts of the gut, except for the cystacanth of $S$. hispida, which often occupied the mesentery of the anterior intestine. The latter species was recorded in $T$. trachurus from the Mediterranean Sea for the first time with a prevalence of $2.5 \%$. A new host record is similarly noted for Acanthocephaloides sp. $(P=1.7 \%)$ recovered from $C$. rhonchus. This carangid also harboured the pomphorhynchid $L$. pagrosomi with a very low prevalence (1.11\%). Breizacanthus irenae, with the relatively important prevalence ( $P=25 \%)$, was collected from $M$. surmuletus. The most widespread acanthocephalan species (generalist) was $T$. exiguus $(\mathrm{P}=35 \%$ in $T$. trachurus and $\mathrm{P}=$ $27.8 \%$ in C. rhonchus). The light and scanning electron microscopy showed that $T$. exiguus exhibited variations in the trunk size and number of proboscis hooks, compared with other previously reported morphological observations (Dezfuli \& Sbrenna, 1990, Kvach \& Sasal, 2010,). These preliminary data enhance the understanding the plasticity of acanthocephalans and promote further taxonomical research within this parasite group in the Mediterranean area.

References:

Dezfuli, B. S., Sbrenna, G. (1990): A morphological and ultrastructural study of Telosentis exiguus (Acanthocephala, Palaeacanthocephala). Bollet. Zool., 57(3): 225 - 232. DOI: 10.1080/11250009009355700

Gargouri, L., Antar, L., Zarrouk, F., Maamouri, F. (2015): The occurrence of acanthocephalans in teleost fish from the Bizerte lagoon, Tunisia. J. Helminthol., 90(1): 96 - 101. DOI: 10.1017/ S0022149X15000048 
KVACH, Y., SASAL, P. (2010): Telosentis exiguus (von Linstow, 1901) (Palaeacanthocephala: Illiosentidae), a generalist parasite of fishes in the Mediterranean basin. Syst. Parasitol., 76: 9 - 18. DOI 10.1007/s11230-009-9222-6

\section{Acanthocephalans of the genus Neoechinorhynchus of the Baikal rift zone}

\section{DARIMA BALDANOVA*, TATIANA KHAMNUEVA}

Institute of General and Experimental Biology, Siberian Branch of the Russian Academy of Sciences, 6, Sakhyanovoy str., 670047 Ulan-Ude, The Republic of Buryatia, Russia

${ }^{*}$ Corresponding author

Neoechinorhynchus Stiles et Hassal, 1905 represents one of the largest genera within Acanthocephala. The latest revision of the genus (Amin, 2002) provided information on 88 species split into two subgenera. Only two species of this genus, namely $N$. rutili and $N$. crassus, were listed in the Key to the parasites of the freshwater fish fauna of the USSR (1987). However, more recent study on Neoechinorhynchus in northeastern Russia (Atrashkevich et al., 2016) showed that the genus is more species-rich there. We examined acanthocephalans of this genus in various cyprinid fishes from the water-bodies of the Baikal basin and found the fragmented presence of a single species $N$. rutili. Its occurrence was restricted to the mouths of the rivers Selenga and Upper Angara and adjacent shallow water zones, and it was absent in the open Baikal as well as the upper and middle streams of the abovementioned rivers. The prevalence of $N$. rutili differed in various fish hosts, being high in Leuciscus idus ( $P=18.4 \%$ ), lower in L. leuciscus baicalensis ( $P=1.4 \%$ ) and low in the Rutilus rutilus $(P=0.6 \%)$. In general, the acanthocephalans of the Baikal Lake, including $N$. rutili, are limnophilic species and we suppose that the favorable conditions could be associated with a high water velocity in the rivers of the Baikal area and the drift of infected intermediate hosts into the lake. Another congeneric species, N. tumidus, was found far from the Baikal in the isolated Lake Baunt (northern Transbaikalia, the River Lena Basin) in Lota lota (70.3 \%), Coregonus lavaretus $(75.3 \%)$ and L. leuciscus baicalensis (26.3\%).

References:

Amin O.M. (2002): Revision of Neoechinorhynchus Stiles \& Hassall, 1905 (Acanthocephala: Neoechinorhynchidae) with keys to 88 species in two subgenera. Syst. Parasitol., 53(1): 1 - 18. https://doi.org/10.1023/A:1019953421835

Atrashkevich G.I., Mikhallova E.I., Orlovskaya O.M., Pospekhov V.V. (2016): Biodiversity of acanthocephalans (Acanthocephala) in freshwater fishes of Asiatic sub-Arctic region. Parazitologiya, 50(4): 263 - 290. [In Russian].

BAUER O.N. (ed). (1987): Key to the parasites of the freshwater fish fauna of the USSR. Vol. 3. Parasitic Metazoans. First Part. Izdat. Nauka, Leningrad., 425 pp. [In Russian]

\section{LIFE CYCLE AND ECOLOGY}

Divergent selective pressures on male and female acanthocephalans: morphological and ecological consequences

FRANCISCO J. AZNAR ${ }^{1}$, JUAN A. RAGA ${ }^{1}$, ENRIQUE A. CRESPO $^{2}$, MAR VILLAR-DE-PABLO ${ }^{1}$, SUSANA CABRERA-GIL', JESÚS S. HERNÁNDEZ-ORTS ${ }^{3 *}$

${ }^{1}$ Instituto Cavanilles de Biodiversidad y Biología Evolutiva, Parque Científico, Universidad de Valencia, Paterna, Valencia, España, Spain

${ }^{2}$ Centro para el Estudio de Sistemas Marinos (CESIMAR - CCT CENPAT-CONICET) and Universidad Nacional de la Patagonia San Juan Bosco (UNPSJB), Puerto Madryn, Chubut, Argentina

${ }^{3}$ Centro de Investigación Aplicada y Transferencia Tecnológica en Recursos Marinos Almirante Storni (CIMAS - CCT CONICET CENPAT ), San Antonio Oeste, Río Negro, Argentina

${ }^{*}$ Corresponding author

Acanthocephalans are dioecious parasites with a polygynous mating system. Both experimental and observational data drawn from several species suggest that males have a shorter life-span and intensely compete for the access to non-mated females, with larger body sizes likely rendering greater reproductive pay-offs. Regardless of whether females are choosy (this is not known), they live longer than males to produce the offspring in suitable microhabitats where nutritional resources are abundant. Accordingly, adult males and females should develop different strategies to face divergent selective pressures. In this presentation, we explore this question in two key aspects, i.e., the investment in holdfast structures, and microhabitat selection, using species of Corynosoma as a model. Firstly, we examined the size of body spines in cystacanths and adults of $C$. australe and $C$. cetaceum. We found that spines grow in both species, but only in females, which also have significantly larger spines than males. This sexual dimorphism does not result from a pure allometry and conform to the hypothesis that females need to withstand the extreme flow conditions prevailing in marine mammals for longer. Secondly, we compared the intestinal distribution of non-mated and mated females, and males, of $C$. australe and $C$. strumosum in two pinniped species. We found that both species share a strikingly similar pattern: the distribution of non-mated females is significantly more anterior than that of mated females, which concentrate in intestinal regions where a nutrient absorption occurs. The distribution of males, however, is significantly more anterior than that of females. Apparently, males, but no females, experience a trade-off between growing in suitable microhabitats and contacting non-mated females that migrate towards these microhabitats. A comparison of body sizes between sexes in $C$. strumosum along the intestine conforms to this interpretation. 
Cryptic species and unexpected intermediate host specificity in the acanthocephalan Polymorphus minutus

\section{MAIKE ZITTEL ${ }^{1}$, DANIEL GRABNER ${ }^{2 *}$, ANNEMIE DOLIWA ${ }^{2}$, ANDRE WLECKLIK ${ }^{3}$, BERND SURES ${ }^{2,4}$, FLORIAN LEESE ${ }^{3}$, HORST TARASCHEWSKI', ALEXANDER WEIGAND ${ }^{3,5}$}

1Department of Ecology and Parasitology, Zoological Institute, Karlsruhe Institute of Technology, Karlsruhe, Germany

${ }^{2}$ Aquatic Ecology and Centre for Water and Environmental Research, University of Duisburg-Essen, Essen, Germany

${ }^{3}$ Aquatic Ecosystem Research Group and Centre for Water and Environmental Research, University of Duisburg-Essen, Essen, Germany

${ }^{4}$ Department of Zoology, University of Johannesburg, Johannesburg, South Africa

${ }^{5}$ Musée National d'Histoire Naturelle, Luxembourg

* Corresponding author

Polymorphus minutus is a bird-infecting acanthocephalan and is the most commonly reported species of this genus in central Europe. Previous data suggests that $P$. minutus comprises of different lineages or even cryptic species exploiting different intermediate hosts. Our aim was to test the genetic diversity of Polymorphus c.f. minutus depending on locality and intermediate host species, to examine if $P$. minutus can be considered a cryptic species. We sampled amphipod intermediate hosts infected with Polymorphus cf. minutus cystacanths originating from 27 sites in Germany and France. Parasites and hosts were identified using integrated datasets (COI and/or morphology for hosts and COI + ITS1-5.8S-ITS2 and morphology for parasites). Mitochondrial and nuclear genetic data strongly supported the existence of three cryptic Polymorphus cf. minutus (type 1-3) species. The morphological analyses indicated minor differences in hook dimensions between the types, while no difference was observed in the analysis with "Proboscis Profiler". The three types revealed a high degree of intermediate host specificity: Polymorphus type 1 was only encountered in Gammarus fossarum type B, Polymorphus type 2 in Echinogammarus sp. and Echinogammarus berilloni, and Polymorphus type 3 in Gammarus pulex and Gammarus roeselii. These results point to a so far neglected cryptic diversity of the genus Polymorphus in Central Europe. Furthermore, Polymorphus type 2 is most likely a non-native parasite in Germany that co-invaded with $E$. berilloni from the Mediterranean area. Potentially, type 3 originated from South-East Europe and migrated to Germany by G. roeselii, where it was captured in G. pulex as intermediate host. Therefore, our findings can be seen in the context of ecological globalization in terms of the anthropogenic displacement of intermediate hosts and its impact on the dispersal of parasite species. Moreover, our data clearly point to a taxonomic revision of Polymorphus c.f. minutus.
Massive infections of Neoechinorhynchus buttnerae in an Amazonian fish, Colossoma macropomum, with notes on the parasites biology

\section{FELIPE DE SOUSA LOURENÇO}

National Institute of Amazonian Research (INPA), Av. André Araújo, 2936, Aleixo, CEP 69060-001, Manaus, Amazonas, Brazil

For over a decade, an acanthocephalan Neoechinorhynchus buttnerae has caused production losses for Colossoma macropomum producers in Brazil. In some cases, the prevalence of the parasite reaches up to one hundred percent being accompanied with high infections causing a morphological damage of the intestine and compromise the growth of the fishes. The life cycle of this parasite was recently described under experimental conditions using intermediates hosts fed with the eggs of adult specimens of $N$. buttnerae collected from C. macropomum. Every stage of the development was photographed, measured, drawn and described. In total, ten larval developmental cycles were studied. This information might help future studies in hopes to control the massive infections in the most produced native fish of Brazil.

References:

Lourenço, F.S., Morey, G.A.M., Malta, J.D.O. (2018): The development of Neoechinorhynchus buttnerae (Eoacanthocephala: Neoechinorhynchidae) in its intermediate host Cypridopsis vidua in Brazil. Acta Parasitol., 63(2): 354 - 359. DOI: 10.1515/ap-20180040

Malta, J.D.O., Gomes, A.L.S., De Andrade, S.M.S., Varella, A.M.B. (2001): Massive infestation by Neoechinorhynchus buttnerae Golvan, 1956 (Eoacanthocephala: Neochinorhynchidae) in young" tambaquis" Colossoma macropomum (Cuvier, 1818) cultured in the Central Amazon. Acta Amazonica, 31(1): 133 - 143. DOI: http://dx.doi.org/10.1590/1809-43922001311143

de Matos, L.V., de Oliviera, M.I.B., Gomes, A.L.S., da Silva, G.S. (2017): Morphological and histochemical changes associated with massive infection by Neoechinorhynchus buttnerae (Acanthocephala: Neoechinorhynchidae) in the farmed freshwater fish Colossoma macropomum Cuvier, 1818 from the Amazon State, Brazil. Parasitol. Res., 116(3), 1029 - 1037. DOI: https://doi.org/10.1007/ s00436-017-5384-3 
Host-switch of Corynosoma australe (Polymorphidae) from mammal seals to bird penguins: exploiting an ancestral resource?

JESÚS S. HERNÁNDEZ-ORTS ${ }^{*}$, MARTHA BRANDÃO2 ${ }^{2}$ SIMONA GEORGIEVA ${ }^{3,4}$, JUAN A. RAGA ${ }^{4}$, ENRIQUE A. CRESPO ${ }^{5}$, JOSÉ L. LUQUE ${ }^{6}$, FRANCISCO J. AZNAR ${ }^{4}$

${ }^{1}$ Centro de Investigación Aplicada y Transferencia Tecnológica en Recursos Marinos Almirante Storni (CIMAS - CCT CENPAT CONICET), San Antonio Oeste, Río Negro, Argentina

${ }^{2}$ Fiocruz Mata Atlântica (CFMA/ Fiocruz), Rio de Janeiro, Rio de Janeiro, Brazil

${ }^{3}$ Institute of Parasitology, Biology Centre, Czech Academy of Sciences, Branišovská 31, 37005 České Budějovice, Czech Republic

${ }^{4}$ Instituto Cavanilles de Biodiversidad y Biología Evolutiva, Parque Científico, Universidad de Valencia, Paterna, Valencia, España, Spain

${ }^{5}$ Centro para el Estudio de Sistemas Marinos (CESIMAR - CCT CENPAT - CONICET) and Universidad Nacional de la Patagonia San Juan Bosco (UNPSJB), Puerto Madryn, Chubut, Argentina ${ }^{6}$ Departamento de Parasitologia Animal, Universidade Federal Rural do Rio de Janeiro, Seropédica, Rio de Janeiro, Brazil

${ }^{*}$ Corresponding author

Corynosoma australe is common acanthocephalan specific to otariid pinnipeds in temperate and sub-Antarctic waters of the Southern Hemisphere. This acanthocephalan is trophically-transmitted and is regularly exposed to hosts and non-hosts through complex food web interactions. In fact, immature specimens of $C$. australe have been reported in higher trophic levels hosts (e.g. sharks, birds and cetaceans) in which apparently, they cannot grow or reproduce. In this study we investigate an apparent host-switching event of $C$. australe, since gravid worms were collected from the intestine of Magellanic penguins Spheniscus magellanicus from Brazil. A morphological study showed that the acanthocephalans from penguins belong to $C$. australe. Partial fragments of the 28S rRNA and mitochondrial cox1 genes were amplified from isolates from penguins and two pinniped species (i.e. South American sea lion Otaria flavescens and South American fur seal Arctocephalus australis) to confirm this identification. Infection parameters clearly differed between penguins and the two pinniped species, which were significantly lower in the former. The sex ratio of $C$. australe also differed between penguins and pinnipeds; in penguins it was strongly biased against males, while in pinnipeds it was close to 1:1. Interestingly, females of $C$. australe from the South American sea lion were significantly smaller than those from penguins and the South American fur seal, but fecundity was lower and more variable in females collected from penguins. At first glance, the occurrence of reproductive individuals of $C$. australe in Magellanic penguins could be interpreted as an adaptive coloniza- tion of a novel avian host through favourable mutations. However, it could also be considered, perhaps more likely, as an example of ecological fitting through the use of a plesimorphic (host) resource, since the ancestors of Corynosoma infected aquatic birds.

\section{BIOLOGY, ACANTHOCEPHALANS IN POLLUTED ENVIRON- MENTS}

Characterization of nutritional relationships between acanthocephalans and their hosts as compared to other hostparasite associations using stable isotope analyses

\section{BERND SURES ${ }^{1,2 *}$, MILEN NACHEV ${ }^{1}$}

${ }^{1}$ Aquatic Ecology and Centre for Water and Environmental Research, University of Duisburg-Essen, Universitätsstrasse 5,

D-45141 Essen, Germany

2Department of Zoology, University of Johannesburg, Johannesburg, South Africa

${ }^{*}$ Corresponding author

Stable isotope analysis of carbon and nitrogen can deliver insights into trophic interactions between organisms. While many studies on free-living organisms are available, the number of those focusing on trophic interactions between hosts and their associated parasites still remains scarce. Information about some taxa such as acanthocephalans or monogeneans is either very limited or even completely missing. Additionally, available data revealed different and occasionally contrasting patterns, which is most likely depending on the parasite's taxonomic position and its degree of development. Among others, we have determined $\delta^{13} \mathrm{C}$ and $\delta^{15} \mathrm{~N}$, in different acanthocephalan-host systems considering larval as well as adult stages of aquatic and terrestrial hosts. Herewith, we are able to evaluate the trophic position of acanthocephalans with respect to their hosts and to analyse a potential trophic level shift associated to the transmission from intermediate to definitive hosts.

In the context of a meta-analysis we have added this information to already existing data for approximately 100 host-parasite associations considering many taxonomic groups of parasites. This data compilation allowed us to describe patterns of nutritional relationships between hosts and their parasites. Taxa such as cestodes, trematodes and acanthocephalans as well as larval nematodes were mostly depleted in ${ }^{15} \mathrm{~N}$. Parasitic crustaceans (Copepoda, Isopoda, Cirripedia) and gastropods showed usually similar or lower isotope values, whereas parasitic insects, arachnids, fish as well as adult nematodes were enriched in ${ }^{15} \mathrm{~N}$ (on average $4.6 \%$ ). In the taxa Cestoda, Trematoda and Acanthocephala processed nutrients provided by the host are assimilated via the body surface. Taxa such as Nematoda, Crustacea, Insecta, Arachnida and others, actively feed on tissues or fluids of their host organisms. Whereas the latter behave similar to micropredators, the nutrient absorbing parasite taxa appear to be commensal-like organisms 
(acanthocephalans, cestodes) with respect to their nutritional strategy.

Combined effects of parasitism and anthropogenic stressors in the freshwater amphipod Gammarus fossarum: Impacts on multiple traits

\section{MARIE-JEANNE PERROT-MINNOT ${ }^{*}$, ARNAUD CHAU- MOT $^{2}$, GWENAELLE CAILLOT ${ }^{1}, 2$, HERVE QUEAU ${ }^{2}$, NICOLAS DELORME ${ }^{2}$, OLIVIER GEFFARD ${ }^{2}$}

1Biogéosciences, UMR 6282 CNRS, Université Bourgogne Franche-Comté, 6 Boulevard Gabriel, 21000 Dijon, France

${ }^{2}$ Equipe d'écotoxicologie - UR Riverly Irstea - Centre de Lyon, 5 rue de la Doua - CS 20244, 69625 Villeurbanne Cedex, France

* Corresponding author

The interest in acanthocephalan fish parasites as model organisms in ecotoxicology increased ever since pioneer studies more than 20 years ago. More recently, the need for assessing multiple stressors has been emphasized, as well as the interest in combining behavioural and physiological responses with life-history traits. We address here whether the infection of the freshwater amphipod Gammarus fossarum with Pomphorhynchus tereticollis interacts with chemical pollutant and temperature. Using a fully crossed factorial design, we investigated whether infection at the population level (naïve populations without parasite historical record vs non-naïve populations with historical records) and at the individual level (infected and uninfected organisms) changes the effect of the carbamate insecticide (methomyl) and the temperature. For this, we assessed the expression of various behavioural and physiological traits (general defence systems), and food intake and survival as components of functional response and fitness respectively. Infection with $P$. tereticollis has pervasive effects on most of the traits measured. At the population level, uninfected gammarids from non-naïve populations exhibited decreased AChE and antioxidant potential, and increased Glutahion-S-transferase activity, lipid perodixation and Pro-phenoloxidase activity. At the individual level, infection induced decreased feeding rate, increased AChE and GST activity, and decreased anti-oxidant potential, lipid peroxidation, and phenoloxidase activity. By contrast, methomyl alone had limited effect, restricted to decreased AchE activity (its target) and feeding rate. We evidenced very few interactions between stressors; however an additive effect of population infection history and methomyl exposure was evidenced on AChE activity and feeding rate. Temperature mainly modulates the effects of other factors - methomyl, population, and infection- therefore making the predictions about the outcome of global changes in temperature complex. Given these pervasive effects of population parasite history and individual infection, parasitism should be taken into account when running ecotoxicological monitoring, to gain realism in their conclusions when adressing ecological risk.

\section{References:}

Holmstrup, M., Bindesbøl, A.M., Oostingh, G.J., Duschl, A., Scheil, V., Köhler, H.R., Loureiro, S., Soares, A.M., Ferreira A.L., Kienle, C., Gerhardt, A., Laskowski, R., Kramarz, P.E. Bayley, M., Svendsen, C., SPURgeOn, D.J. (2003). Interactions between effects of environmental chemicals and natural stressors: a review. Sci. Total Environ., 408(18): 3746 - 3762. DOI: 10.1016/j.scitotenv.2009.10.067. Sures B., Siddall, R., Taraschewski, H. (1999). Parasites as accumulation indicators of heavy metal pollution. Parasitol. Today, 15(1): 16 - 21. https://doi.org/10.1016/S0169-4758(98)01358-1

\section{Mechanistically modelling metal accumulation in fish-para- site systems: Ongoing attempts}

T.T. YEN LE ${ }^{1 *}$, MIRIAM R. GARCIA ${ }^{2}$, MILEN NACHEV ${ }^{1}$, DANIEL GRABNER ${ }^{1}$, EVA BALSA-CANTO ${ }^{2}$, JAN A. HENDRIKS ${ }^{3}$, BERND SURES

${ }^{1}$ Aquatic Ecology and Centre for Water and Environmental Research, University of Duisburg-Essen, Universitätsstrasse 5,

D-45141 Essen, Germany

${ }^{2}$ Spanish Council for Scientific Research (CSIC), Vigo, Spain

${ }^{3}$ Radboud University Nijmegen, Comeniuslaan 4, 6525 HP Nijmegen, the Netherlands

${ }^{*}$ Corresponding author

Fish are affected by both, exposure to metals and infection with parasites. Each of these stressors might have effects on the response of fish to the other. Some efforts have recently been done in developing kinetic models for a prediction of the metal accumulation in fish-parasite systems. Our previous model allows the investigation of relationships between its accumulation in the fish and acanthocephalans, but does not include the mechanisms how metals are accumulated in parasites. Physiologically-based pharmacokinetic (PBPK) model has been used for simulating the organ-specific accumulation of chemicals. However, the capacity of this model for mimicking fish-parasite systems has not been investigated. We aimed to integrate mechanisms for the simulation of metal accumulation in the system of the chub Squalius cephalus and acanthocephalan Pomphorhynchus tereticollis by developing of PBPK model, in which acanthocephalans were considered a compartment, similar to the blood, storages (muscle, skin, bone, and carcass), gill, kidney, liver, and intestine. The metal accumulation in the system was modelled as a function of internal (i.e. exchange between different compartments) and external (i.e. exchange with water) factors. The flow from the blood to the other compartments depends on diffusive exchange and fraction of metals dissolved in the blood plasma. The flow to the blood is a function of diffusive exchange and blood-tissue partitioning. The model was calibrated by MATLAB-based AMIGO Toolbox. As a detoxifying organ, the liver was found to accumulate Ag at the highest level. Initial results from the model calibration for $\mathrm{Ag}$ show a good 
potential of the model for simulation the accumulation in the muscle, gill, and liver. However, further attempts are being examined to improve the efficiency of the model in simulation of Agdelayed accumulation in the intestine as well as in acanthocephalans.

Comparison of the metal accumulation capacity of acanthocephalans from fish and mammalian definitive hosts

\section{MILEN NACHEV ${ }^{1 *}$, HALIMA JMII CHINE ${ }^{2}$, KRISTINA LEH- NERT $^{3}$, LAMIA GARGOURI ${ }^{2}$ AND BERND SURES ${ }^{1,4}$}

${ }^{1}$ Aquatic Ecology and Centre for Water and Environmental Research, University of Duisburg-Essen, Universitätsstrasse 5,

D-45141 Essen, Germany

${ }^{2}$ Research Unit Bio-Ecology and Evolutionary Systematic, Faculty of Sciences of Tunis, University of Tunis El Manar, 2092, Tunis, Tunisia

${ }^{3}$ Institute for Terrestrial and Aquatic Wildlife Research, University of Veterinary Medicine Hannover, Werftstrasse 6, 25761 Buesum, Germany

${ }^{4}$ Department of Zoology, University of Johannesburg, Johannesburg, South Africa

${ }^{*}$ Corresponding author

Recent research on the metal accumulation potential of parasites provided strong evidence that various taxa can be used as sentinels for metal pollution. Among the taxa of parasites tested so far with respect to their metal accumulation capacity acanthocephalans have been found to accumulate metals to a much higher degree than the host and the host's surrounding environment. However, until now, most studies focused on limnetic host-parasite associations, whereas only few papers considered marine acanthocephalan-host systems. Moreover, most studies were performed on fish as definitive hosts, information about the accumulation potential of acanthocephalans from (marine) mammals is scarce. Here, we summarize data of several metal accumulation studies that were performed on marine acanthocephalans (belonging to the genera Neoechinorhynchus and Corynosoma) collected from their definitive fish (different species of mullets, Mugelidae) and mammalian hosts (common seal, Phoca vitulina). Moreover, based on a well-studied limnetic acanthocephalan species (Pomphorhynchus laevis from its cyprinid host) we also address the usefulness of acanthocephalans as sentinel organisms for rare earth elements (REE), which are - although being present only in low environmental concentrations - mainly introduced into ecosystems due to anthropogenic activities. The results confirmed that acanthocephalans from fish accumulated various elements to a higher extend than the host itself. This trend was found for both essential (e.g. Cu, Mn, Zn) and non-essential metals (e.g. Cd, $\mathrm{Pb}$ ) as well as for some REE, especially when compared to host's muscle tissue. Acanthocephalans from the mammalian host did not show such pronounced accumulation patterns and the concen- trations of most elements were lower or comparable to those found for kidney or liver tissue. Interestingly, several elements such as $\mathrm{Ag}, \mathrm{Cd}, \mathrm{Mn}, \mathrm{Ni}$ and $\mathrm{V}$ were accumulated to a higher degree in the parasite compared to muscle, intestine and stomach tissue of the host. The differences in accumulation patterns will be discussed with respect to differences in pollution levels of the host's habitats and also to differences in uptake mechanisms and metabolism of metals in mammalian and fish hosts.

Insights from chub - acanthocephalan system in polluted environments: Towards host decontamination?

\section{NOËLIE MOLBERT ${ }^{1 \star}$, FABRICE ALLIOT ${ }^{1,2}$, VINCENT MEDOC 3,4, JEAN-MARIE MOUCHEL', AURELIE GOUTTE ${ }^{1,2}$}

${ }^{1}$ Sorbonne Université, CNRS, EPHE, Milieux environnementaux, transferts et interactions dans les hydrosystèmes et les sols, METIS, F-75005 Paris, France

${ }^{2}$ EPHE, PSL, Sorbonne Université, CNRS, Milieux environnementaux, transferts et interactions dans les hydrosystèmes et les sols, METIS, F-75005 Paris, France

${ }^{3}$ Sorbonne Université, CNRS, Institut d'Ecologie et des Sciences de l'Environnement de Paris, IEES, F-75005 Paris, France ${ }^{4}$ Université Jean Monnet, 42100 Saint-Etienne, France *Corresponding author: noelie.molbert@upmc.fr

Few studies have investigated the accumulation and metabolisation of organic micropollutants in host-parasite systems despite their ubiquity, chronic release and potentially higher toxicity of their metabolites. The fate of organic pollutants in host-parasite systems was examined in a freshwater fish, the chub Squalius cephalus, naturally infected by acanthocephalan Pomphorhynchus laevis. Infected $(\mathrm{N}=74)$ and uninfected fish $(\mathrm{N}=55)$ were caught by electrofishing operations from the Marne River and its tributaries in September 2016. The occurrence and levels of several persistent micropollutant families (polychlorinated biphenyls (PCBs), organochlorine pesticides (OCPs), polybrominated diphenyl-ethers (PBDEs)) and metabolizable ones (polycyclic aromatic hydrocarbons (PAHs), phthalates, pyrethroid pesticides), as well as their metabolites, were characterized in parasites and various tissues of the fish (muscle, liver and stomach content). Infected chub were significantly less contaminated by OCPs $(P \leq 0.01)$ but had higher levels of pyrethroid pesticides $(P \leq 0.05)$ than uninfected fish. PAHs and phthalates reached higher levels in the acanthocephalans than in chub tissues ([ $\left.\left.\mathrm{C}_{\text {[P.laevis] }} / \mathrm{C}_{\text {[chub tissue }]}\right]>1\right)$. The highest concentrations of PAHs were detected in parasites (Median [Min ; Max], in ng.g ${ }^{-1}$ of dry weight (dw), 1922 [875.64 ; 9779.30]), followed by the stomach content (591.80 [321.28 ; 1714.17]), liver (92.29 [0.34; 637.39]) and muscle (6.74 [0.89 ; 147.76]), with levels up to 5,000 times higher in parasites than in the host muscle. Our results suggest (1) a potential transfer of organic pollutants from the host to parasites, (2) a lower ability 
for parasites to metabolize these compounds and/or (3) a higher sensitivity of parasites to the pollution compared to their fish host. Experimental validations will be conducted to confirm this host decontamination by acanthocephalans and the potential benefits for chubs, through the analysis of suitable biomarkers for a host health assessment (oxidative stress, immunity, body condition).

Application of acanthocephalans as bioindicators of metal exposure in the karst Krka River influenced by industrial and municipal wastewaters

VLATKA FILIPOVIĆ MARIJIĆ*, TATJANA MIJOŠEK, ZRINKA DRAGUN, NESRETE KRASNIĆI, DUŠICA IVANKOVIĆ, MARIJANA ERK

Ruđer Bošković Institute, Division for Marine and Environmental Research, Laboratory for Biological Effects of Metals, P.O. Box 180, 10002 Zagreb, Croatia

${ }^{*}$ Corresponding author

Naturally present trace metal concentrations in rivers are low, even extremely low in karst rivers, which make them very sensitive to the anthropogenic influence. The Krka River is a typical karst river in the Republic of Croatia whose lower part was proclaimed a National Park due to its exceptional natural beauty. The aim of the present study was to evaluate metal exposure in the Krka River few kilometres upstream of the park border, in the area threatened by industrial and municipal wastewaters, using bioindicator organisms: fish brown trout (Salmo trutta Linnaeus, 1758), gammarids (Gammarus fossarum Koch, 1836) and fish intestinal parasites, acanthocephalans (Dentitruncus truttae Sinzar, 1955). During the last few decades, acanthocephalans were recognized as potential indicators of metal exposure in the aquatic environment due to their effective metal accumulation, which is order of magnitude higher, compared to commonly used bioindicator organisms (Sures et al., 2017). Concentrations of 16 microelements and 4 macroelements were measured in digested fish intestine, gammarids and acanthocephalans from the Krka River source as a reference site and downstream with the wastewater impact. Prior to metal measurement by high resolution inductively coupled plasma-mass spectrometer (HR ICP-MS), samples were acid digested in a drying oven at $85^{\circ} \mathrm{C}$ for 3.5 hours using concentrated $\mathrm{HNO}_{3}$ and $\mathrm{H}_{2} \mathrm{O}_{2}$. The prevalence of acanthocephalans in fish from the reference site was $100 \%$ and from the polluted area $80 \%$, while the mean intensity of infection per fish was around 30 in both locations. More effective accumulation of most metals was found in acanthocephalans compared to fish and gammarids in both locations, especially of toxic $\mathrm{Cd}, \mathrm{Pb}, \mathrm{Sr}$ and $\mathrm{Tl}$, in which average levels were 4-39 times higher in acanthocephalans. Metal concentrations were mostly higher in organisms from the wastewater impacted area, confirming anthropogenic influence and useful contribution of acanthocephalans as sensitive bioindicators of bioavailable metal levels.

\section{References:}

Sures, B. Nachev, M., Selbach, C., Marcogliese, D.J. (2017): Parasite responses to pollution: what we know and where we go in 'Environmental Parasitology'. Parasit. Vectors, 10: 65. DOI: 10.1186/ s13071-017-2001-3

\section{Accumulation of heavy metals in fishes and its parasites from} the Ružín water reservoir, biomonitoring study

\section{TIMEA BRÁZOVÁ*, PETER ŠALAMÚN, INGRID PAPAJOVÁ}

Institute of Parasitology, Slovak Academy of Sciences, Hlinkova 3, 04001 Košice, Slovakia

*Corresponding author e-mail: barciova@saske.sk

In this study, the actual content of 10 heavy metals was analysed in different organs of European perch (Perca fluviatilis L.) as well as its parasites (Acanthocephalus lucii, Proteocephalus percae) from the Ružín water reservoir. Heavy metals from reservoir sediments accumulated mostly in the kidneys (almost 30-times more than in fish muscles). Toxic lead was mostly concentrated in fish bones. In the muscles of perch, the only mercury exceeded the maximum permissible level $\left(1.05 \mathrm{mg}^{\mathrm{kg}}{ }^{-1}\right.$; limit $\left.0.5 \mathrm{mg} \cdot \mathrm{kg}^{-1}\right)$. Concerning toxic element accumulation, acanthocephalans, in comparison to the tapeworms and fish organs, absorbed them most intensively. The study was supported by VEGA project No. 2/0125/17. 